\title{
Thermodynamic and Environmental Assessment of Gas Flaring in the Niger Delta Region of Nigeria
}

\author{
Richard V. James, Howells I. Hart, Barinyima Nkoi \\ Mechanical Engineering Department, Rivers State University, Port Harcourt, Nigeria \\ Email: nengiv@yahoo.com
}

How to cite this paper: James, R.V., Hart, H.I. and Nkoi, B. (2018) Thermodynamic and Environmental Assessment of Gas Flaring in the Niger Delta Region of Nigeria. Journal of Power and Energy Engineering, 6, 39-56.

https://doi.org/10.4236/jpee.2018.612003

Received: November 2, 2018

Accepted: December 25, 2018

Published: December 28, 2018

Copyright $\odot 2018$ by authors and Scientific Research Publishing Inc. This work is licensed under the Creative Commons Attribution International License (CC BY 4.0).

http://creativecommons.org/licenses/by/4.0/

\begin{abstract}
This paper discusses the thermodynamic and environmental assessment of flared gases in an oil field. The oil field for the case study is located in the Niger Delta region of Nigeria. The data required for this report were obtained during a nine-year period (2008-2016), which revealed production volumes, flared volumes, operating temperatures and pressures, gas compositions, gas density, and flow rates. With the data and the aid of fundamental thermodynamic equations and MATLAB program codes, analysis was carried out on combustion to ascertain the amount of flue gases. Analyses revealed that a total of $1.99175 \times 10^{11}$ standard cubic feet of gas was flared during the said period, generating anthropogenics estimated at $582,319,618.1825 \mathrm{~m}^{3}(\approx 1.046$ Mt) of $\mathrm{CO}_{2}, 1,077,510,054.31 \mathrm{~m}^{3}(\approx 2.0 \mathrm{Mt})$ of water vapour, $14,960,560.91 \mathrm{~m}^{3}$ of methane emitted and contaminated the atmosphere creating serious environmental concerns. Further analyses also showed that the approximate adiabatic flame temperature is about $1965^{\circ} \mathrm{C}$ for the field under investigation. Exergy analyses carried out also revealed that a total of $3.6099 \times 10^{13} \mathrm{~kJ}$ $(36.099 \mathrm{TJ})$ of exergy was available which would have translated to $1.0189 \times$ $10^{10} \mathrm{kWh}$ of electrical energy for the period under investigation. Conclusively, some measures that can be taken to prevent gas flaring are that every new project on oil and gas should incorporate technical details of gas gathering and utilization plan at the conceptual and design phases of projects for gas commercialization, establishment of more gas-to-power project for gas utilization. Also Carbon capture technology should be enhanced, although the best option is flaring out based on the astronomical amount of carbon (IV) oxide and other greenhouse gases depicted by the results. The entire work and results showed that gas flaring is undesired and pernicious because it has thermal, environmental and economic consequences.
\end{abstract}




\section{Keywords}

Combustion, Exergy, Adiabatic Flame Temperature, Gas Flaring, Carbon (IV) Oxide

\section{Introduction}

Throughout human evolution and history, significant advancement in human development has been accomplished with increase in energy consumption, especially electricity, and this has a tie with population explosion. Energy consumption correlates with industrialization and standard of living of any society [1]. It is indeed irrefutable that oil and gas exploration and production activities play a central role and have economic gains for countries that have such natural resource. It provides wealth creation as well as building a sustained economy all over the world especially if well managed [2]. However, it is worthwhile to state that there are negative consequences of crude oil extraction. Crude oil is a combination of oil, gas, water and other impurities. This gas associated with the crude oil is known as associated natural gas. Ideally this associated gas would have been harnessed and sold to consumers or for electricity generation. This however requires costly investment in pipelines, gas gathering facilities, power plants and others related infrastructure. In practice therefore, oil multinationals opt to sell the oil and flare the gas, which is known as gas flaring. In Nigeria, crude oil was discovered in commercial quantity in 1956 in Oloibiri, present day Bayelsa State, and ever since, gas has continually been flared. This is because at the time, the gas was seen as a nuisance by-product and much was not known about the potential of natural gas and its processing facilities were non-existent, therefore flaring was the only option. Another reason why there is continuous flare of gas is complacence of multi-national companies. On a global scale, Nigeria is currently the seventh largest gas-flaring country as against the second largest over the last 10 years [3], indicating there are tremendous efforts to cut down gas flaring. In Nigeria, access to reliable and sustained supply of electricity is a major challenge for both the urban and rural dwellers. Several analyses of Nigeria's electricity supply problems and prospects posit that electricity demand far outstrips the supply [4]. Nigeria generates barely $4000 \mathrm{MW}$ of electricity, which is grossly inadequate for her population, but tremendously wastes a recognized source of energy for more than five decades now. It is against this back drop that this research is conceived to thermo-mechanically and environmentally assess issues of gas flaring, which if harnessed can be used to fire gas turbines, heat to generate steam for steam turbines, gas-to-liquid conversion using the Fischer-Tropsch process, collection, compression and reinjection into oil wells for enhanced oil recovery, and Liquefied Natural Gas and other perceived uses.

In most of the literatures reviewed, it was observed that the effects of gas flares is mostly thermal related as a result of the exit temperatures of the flares, with a 
huge consequence on the natural environment. Reference [5] developed a model for an accurate prediction of heat flux at any point within the vicinity of gas flares through numerical methods. Reference [6] looked at the effects of gas flaring on the basis of the amount of carbon dioxide released using four villages in the Niger Delta region as a case study, their studies showed that the volume of $\mathrm{CO}_{2}$ produced is greater than the critical threshold limit (about 30,000 ppm). Reference [7] however used a system of differential equations in their model analysis to get the amount of flared gas. The report by [8] showed that gas flaring, especially thermal impacts affects soil temperature, soil moisture content, soil PH, soil microbes. There is a general opinion by [6], [8] and [9] that flaring also contaminates water bodies thereby having a direct impact on water aquifers and aquatic community. Reference [9], did an extensive work on the impacts of gas flaring as it concerns environmental contaminants, health consequences, socio-economic problems and degradation of host communities. Their studies revealed that incomplete combustion produces a variety of volatile organic compounds (VOCs), polycyclic aromatic hydrocarbons (PAHs) and inorganic contaminants. Reference [10] also added that acid rain and soot deposited on roofs is another factor that environmentally degrades soil, water, and roof erosion. Thus, the concentration of acid in rain water appears to be higher in the Niger Delta region and decreases further away from the region. Reference [11] investigated lengths and widths of crops leaves, height of crop plant and Cassava yields were measured at specific distances from a case study flare point. The results suggest that spatial gradients exist in crop development. Their results further showed that Cassava yields were higher in areas further away from the flare points. This is a consequence of thermal pollution within the flare perimeter.

From exergy point of view, [12] in their paper worked on extended exergy accounting method within which they quantified environmental externality linked to the chemical pollutants released by an elevated flare stack. The work provided both the exergy flux released into the environment by the flare stack and the cost in primary resource equivalents. Reference [13] on their part used exergy analysis to evaluate the environmental impact potential of systems and improved the performance of the systems through reduction of waste emissions. The asserted that exergy is released by a system that is not in thermodynamic equilibrium with the environment. They further posited that the release of emissions by our systems is tantamount to the release of exergy into the environment, which not only limit the efficiency of the system and waste our resources, but also contribute to the global warming of our planet. Again, there is similarity between the works of [12], [13], and [14], but it was observed that [14], on their part did extensive work on exergy analysis on waste emission from gas flares to have a model through which impact of gas flaring can be measured, they went further to develop exergy calculator. Although in their analyses, the gas stream was modelled as a perfect gas, and perfect gas relations and equations were used, which at this level of study should not suffice. Reference [15] Used exergy accounting and rules of thumb, Aspen plus, Dynamic Network analysis, and Aspen 
HYSYS to evaluate and assess the thermodynamic performance of an oil and gas platform. They attributed $62 \%-65 \%$ of total exergy destruction of the offshore platform to the power generation and waste heat recovery system, and 35\% $38 \%$ to the oil and gas processing. They affirmed that the rejection of high-temperature gases from utility and flaring systems is a major contributor to the exergy losses. Some of the drawbacks this paper identifies and in most of the literatures reviewed, carbon capture technology was not incorporated with thermal and environmental analysis in most papers. Furthermore, heat fluxes were exhaustively calculated in this work, which $\mathrm{x}$-rayed the effects of heat on soil $\mathrm{PH}$, soil microbes, low yield of vegetation amongst others. Another monumental achievement of this paper is the aggregated fuel composition shown in Table 2.

\section{Material and Method}

\subsection{Overview of Gas Flaring}

Gas flaring has been a contentious issue and still a contemporary issue being discussed around the globe, especially in oil and gas producing countries where flaring activities are predominant. It occurs in the process of crude oil production and processing. Reference [16] and [17] in their separate papers stated that gas flaring is the process of controlled burning of natural gas from oil wells, gas wells, hydrocarbon processing plants, coal industries either as a means of disposal or as a safety measure. The idea of flaring is because it is perceived as the financially cheapest possible means of disposal of natural gas in the short term [17]. Reference [18] also posited that the process of flaring is carried out using flare stack which may be vertical or horizontal.

Gas flaring is a significant source of greenhouse gases such as methane $\left(\mathrm{CH}_{4}\right)$, carbon dioxide $\left(\mathrm{CO}_{2}\right)$, water vapour and other emissions with a consequence of noise generation, increased ambient temperature and provides large area inhabitable. Furthermore, it is a known fact that there are two options for gas utilization instead of outright flaring: the first option is gas utilization for domestic and commercial purposes, which inevitably involves equipment acquisition for liquefaction and transportation. The second option is reinjection for enhanced oil recovery. In lots of countries, Nigeria inclusive, the law prohibits gas flaring because it is harmful to natural ecological systems and constitutes huge loss of revenue.

\subsection{Data Collection}

The data required for this investigation was obtained for a period of Nine (9) Years. The data was sourced for on volume of gas flared in an oil field designated as the Alpha field in the Niger Delta region of Nigeria within. It has two oil fields, but the research effort is concentrated on one of the fields. The field data such as well pressures, mass flow rate, oil-to-gas ratio, discharge velocity, flame height, ambient temperature, well outlet temperature, operating stack tempera- 
ture, gas composition, stack height, were retrieved from the company's log sheets, interviewing of key personnel, email correspondences and field visitations.

\subsection{Combustion Analyses}

Combustion by definition is a process of rapid oxidation of combustible elements of a fuel resulting in the release of energy and products of combustion. Several combustion equations were encountered. However, the equation model by [19] was used, that when $1 \mathrm{kmol}$ of a stream of gas with volumetric compositions: $\mathrm{CH}_{4}-a \%, \mathrm{C}_{2} \mathrm{H}_{6}-b \%, \mathrm{C}_{3} \mathrm{H}_{8}-c \%, \mathrm{C}_{4} \mathrm{H}_{10}-d \%, \mathrm{~N}_{2}-e \%$, the combustion equation is given as:

$$
\begin{aligned}
& \left(\frac{a}{100}\right) \mathrm{CH}_{4}+\left(\frac{b}{100}\right) \mathrm{C}_{2} \mathrm{H}_{6}+\left(\frac{c}{100}\right) \mathrm{C}_{3} \mathrm{H}_{8}+\left(\frac{d}{100}\right) \mathrm{C}_{4} \mathrm{H}_{10}+\left(\frac{e}{100}\right) \mathrm{N}_{2} \\
& +\frac{[a+2 b+3 c+4 d+(2 a+3 b+4 c+5 d) / 2]}{100}\left(\mathrm{O}_{2}+3.76 \mathrm{~N}_{2}\right) \\
& \rightarrow \frac{a+2 b+3 c+4 d}{100} \mathrm{CO}_{2}+\frac{2 a+3 b+4 c+5 d}{100} \mathrm{H}_{2} \mathrm{O} \\
& +\left[3.37\left(\frac{[a+2 b+3 c+4 d+(2 a+3 b+4 c+5 d) / 2]}{100}\right)+\frac{e}{100}\right] \mathrm{N}_{2}
\end{aligned}
$$

From Equation (1), if we know the composition of the natural gas, the aggregated carbon to hydrogen ratio in the gas can be evaluated.

\section{Estimation of Carbon (IV) Oxide}

To estimate the amount of Carbon (IV) Oxide and water vapour the equation by [20], is used, and is expressed as:

$$
M A S S_{\mathrm{CO}_{2}}=\frac{M_{\text {flared gas }} \times M M_{\mathrm{CO}_{2}}}{M M_{\text {fuel }}}(\mathrm{kg})
$$

where, $M A S S_{\mathrm{CO}_{2}}$ is mass of carbon (IV) oxide, $M_{\text {flared gas }}$ - mass of flared gas (kg), $M M_{\mathrm{CO}_{2}}$ - molecular mass of $\mathrm{CO}_{2} ; M M_{\text {fuel }}$-molecular mass of the fuel (gas stream). Equation (2) used is an attempt to check the percentage correlation by this research and that proposed by [20].

\subsection{Adiabatic Flame Temperature (AFT)}

Adiabatic flame temperature is a parameter in combustion that describes the maximum theoretical temperature attained by the combustion products (flue gases), if no exergy is lost to the outside environment [21]. It is evaluated using the equations:

$$
Q=\Delta H^{c}=H_{P}-H_{R}
$$

when the process is adiabatic,

$$
H_{P}=H_{R}
$$

where: 


$$
H_{P}=\sum_{e}^{P} n_{e}\left(\begin{array}{c}
\left.\bar{h}_{o}+\bar{h}-\bar{h}_{o}\right)_{e} \\
f
\end{array}\right.
$$

Also

$$
H_{R}=\sum_{e}^{R} n_{i}\left(\begin{array}{c}
\bar{h}_{o}+\bar{h}-\bar{h}_{o} \\
f
\end{array}\right)_{i}
$$

where, $Q$ is the heat transfer, $\bar{h}_{o}$ is the enthalpy of formation $n_{e}$ and $n_{i}$ are number of moles of products and reactants respectively. $P \& R$ are parameters for products and reactants respectively.

Also, $\bar{h}-\bar{h}_{o}=\bar{\Delta}_{h}$, is the difference in enthalpy for a particular temperature and that of the reference temperature usually $298 \mathrm{k}\left(25^{\circ} \mathrm{C}\right)$, and values are gotten from Jadranski naftovod (JANAF) thermodynamic data Tables.

\subsection{The Concept of Exergy}

Exergy $\left(E_{X}\right)$ of a system also known as availability is the maximum theoretical work obtainable between the system and a specified reference environment when they interact [1]. It is based on the first and second laws of thermodynamics.

Two types of exergies exist. These are thermo-mechanical exergy or physical exergy and Chemical exergy.

\subsubsection{Thermo-Mechanical or Physical Exergy}

The thermo-mechanical (physical) exergy depicts the deviation in temperature and pressure between the flowing matter and that in the reference environment [21].

The thermo-mechanical exergy is expressed as:

$$
\begin{gathered}
e_{x, T M}=E_{x, \text { nonflow }}+E_{x, \text { flow }} \\
e_{x, T M}=\left(U-U_{o}\right)+P_{o}\left(V-V_{o}\right)-T_{o}\left(S-S_{o}\right)+\frac{1}{2} m c^{2}+m g z+\left(P-P_{o}\right) V
\end{gathered}
$$

where, $E_{x, \text { nonflow }}$ is non-flow exergy; $E_{x, \text { flow }}$ is flow exergy; $P_{o}$-surroundings pressure (kpa).

Dividing Equation (8) by mass, all properties becomes specific and will therefore transform to:

$$
\begin{gathered}
e_{x, T M}=(u+P v)-\left(u_{o}+P_{o} v_{o}\right)-T_{o}\left(s-s_{o}\right)+\frac{1}{2} c^{2}+g z \\
e_{x, T M}=\left(h-h_{o}\right)-T_{o}\left(s-s_{o}\right)+\frac{1}{2} c^{2}+g h(\mathrm{~kJ} / \mathrm{kg})
\end{gathered}
$$

But the kinetic and potential exergy terms are negligibly small as compared to the enthalpy and entropy terms, and are therefore neglected.

$$
e_{x, T M}=\left(h-h_{o}\right)-T_{o}\left(s-s_{o}\right)
$$

$h$-specific enthalpy of the system $(\mathrm{kJ} / \mathrm{kg}) ; s$-specific entropy of the system $(\mathrm{kJ} / \mathrm{kg} \mathrm{K}) ; h_{o}$-surroundings specific enthalpy $(\mathrm{kJ} / \mathrm{kg}) ; s_{o}$-surroundings spe- 
cific entropy $(\mathrm{kJ} / \mathrm{kg} \mathrm{K}) ; T_{o}$-surroundings reference temp. (K). Equation (10) will be expanded in Chapter 3 .

\subsubsection{Chemical Exergy}

The chemical exergy of a substance is the maximum work obtainable from a system by taken it to chemical equilibrium with a reference environment at constant temperature and pressure. It is evaluated using:

$$
\begin{aligned}
e_{x, c h}= & {\left[\bar{g}_{F}+\left(a+\frac{b}{4}\right) \bar{g}_{\mathrm{O}_{2}}-a \bar{g}_{\mathrm{CO}_{2}}-\frac{b}{2} \bar{g}_{\mathrm{H}_{2} \mathrm{O}}\right]\left(T_{o}, P_{o}\right) } \\
& +R T_{o} \ln \left[\frac{\left(y_{\mathrm{O}_{2}}^{e}\right)^{a+b / 4}}{\left(y_{\mathrm{CO}_{2}}^{e}\right)^{a}\left(y_{\mathrm{H}_{2} \mathrm{O}}^{e}\right)^{b / 2}}\right]
\end{aligned}
$$

where, $R$-universal gas constant $(\mathrm{kJ} / \mathrm{kmolK}) ; y^{e}$-mole fractions of environmental composition; $\bar{g}$-molar Gibbs function component obtained from standard thermo-mechanical properties tables [21].

\subsection{Total Specific Exergy Computation}

The total specific exergy is the combination of the specific thermo-mechanical exergy and the specific chemical exergy given as:

$$
\begin{gathered}
e_{x, T}=e_{x, T M}+e_{x, c h} \\
e_{x, T}=\left(h-h_{o}\right)-T_{o}\left(S-S_{o}\right) \\
+\left[\bar{g}_{F}+\left(a+\frac{b}{4}\right) \bar{g}_{\mathrm{O}_{2}}-a \bar{g}_{\mathrm{CO}_{2}}-\frac{b}{2} \bar{g}_{\mathrm{H}_{2} \mathrm{O}}\right]\left(T_{o}, P_{o}\right) \\
+R T_{o} \ln \left[\frac{\left(y_{\mathrm{O}_{2}}^{e}\right)^{a+b / 4}}{\left(y_{\mathrm{CO}_{2}}^{e}\right)^{a}\left(y_{\mathrm{H}_{2} \mathrm{O}}^{e}\right)^{b / 2}}\right]
\end{gathered}
$$

\subsection{The Absolute Exergy $\left(E_{X, T}\right)$}

The total or absolute exergy is computed as follows:

$$
\begin{aligned}
E_{X, T}= & \text { mass of gas stream }(m) \times e_{x, T} \\
= & m\left[\left(h-h_{o}\right)-T_{o}\left(S-S_{o}\right)+\left[\bar{g}_{F}+\left(a+\frac{b}{4}\right) \bar{g}_{\mathrm{O}_{2}}-a \bar{g}_{\mathrm{CO}_{2}}\right.\right. \\
& \left.\left.-\frac{b}{2} \bar{g}_{\mathrm{H}_{2} \mathrm{O}}\right]\left(T_{o}, P_{o}\right)+\left[\frac{\left(y_{\mathrm{O}_{2}}^{e}\right)^{a+b / 4}}{\left(y_{\mathrm{CO}_{2}}^{e}\right)^{a}\left(y_{\mathrm{H}_{2} \mathrm{O}}^{e}\right)^{b / 2}}\right]\right](\mathrm{kJ})
\end{aligned}
$$

\section{Heat flux density by Radiation}

Heat flux is referred to as the flow of heat energy per unit area per unit time. The Stefan-Boltzmann equation describes the rate of transfer by radiant energy as:

$$
\text { Heat flux, } Q=\sigma \epsilon T^{4}
$$


where, $Q$-heat flux $\left(\mathrm{W} / \mathrm{m}^{2}\right) ; \epsilon$-emissivity of the surface/source (which is one in this case); $T$-temperature in kelvin (K); $\sigma$-Stefan-Boltzmann constant $\left(5.67 \times 10^{-8} \mathrm{~W} / \mathrm{m}^{2}\right)$.

\section{Results and Discussion}

The data shown in Table 1 correlates with average gas compositions for each year.

\subsection{Combustion Analysis}

The following are useful assumptions:

1) The fuel entered the flare stack at $25^{\circ} \mathrm{C}$ and 1 atm while the air at $27^{\circ} \mathrm{C}$.

2) Flow is steady.

3) Water at the product side is vapour.

Using Equation (1), and substituting values, for $1 \mathrm{kmol}$ of the fuel we have: With $a=93.9 ; b=3.6 ; c=1.3 ; d=1.2 ; e=0$ [for the first year, 2008]

$$
\begin{aligned}
& \quad\left(\frac{a}{100}\right) \mathrm{CH}_{4}+\left(\frac{b}{100}\right) \mathrm{C}_{2} \mathrm{H}_{6}+\left(\frac{c}{100}\right) \mathrm{C}_{3} \mathrm{H}_{8}+\left(\frac{d}{100}\right) \mathrm{C}_{4} \mathrm{H}_{10}+\left(\frac{e}{100}\right) \mathrm{N}_{2} \\
& +\frac{\left[a+2 b+3 c+4 d+\frac{2 a+3 b+4 c+5 d}{2}\right]}{100}\left(\mathrm{O}_{2}+3.76 \mathrm{~N}_{2}\right) \\
& \rightarrow \frac{a+2 b+3 c+4 d}{100} \mathrm{CO}_{2}+\frac{2 a+3 b+4 c+5 d}{100} \mathrm{H}_{2} \mathrm{O} \\
& +\left[3.37\left(\frac{[a+2 b+3 c+4 d+(2 a+3 b+4 c+5 d) / 2]}{100}\right)+\frac{e}{100}\right] \mathrm{N}_{2} \\
& 0.939 \mathrm{CH}_{4}+0.036 \mathrm{C}_{2} \mathrm{H}_{6}+0.013 \mathrm{C}_{3} \mathrm{H}_{8}+0.012 \mathrm{C}_{4} \mathrm{H}_{10}+2.147\left(\mathrm{O}_{2}+3.76 \mathrm{~N}_{2}\right) \\
& \rightarrow 1.098 \mathrm{CO}_{2}+2.098 \mathrm{H}_{2} \mathrm{O}+8.07272 \mathrm{~N}_{2}
\end{aligned}
$$

\begin{tabular}{|c|c|c|c|c|c|}
\hline Natural gas sample & Methane $\left(\mathrm{CH}_{4}\right) \%=a$ & Ethane $\left(\mathrm{C}_{2} \mathrm{H}_{6}\right) \%=b$ & Propane $\left(\mathrm{C}_{3} \mathrm{H}_{8}\right) \%=c$ & Butane $\left(\mathrm{C}_{4} \mathrm{H}_{10}\right) \%=d$ & Other incombustibles $=e$ \\
\hline$A(2008)$ & 93.90 & 3.60 & 1.30 & 1.20 & 0.00 \\
\hline B (2009) & 91.35 & 4.00 & 2.8 & 1.22 & 0.63 \\
\hline$C(2010)$ & 90.44 & 4.50 & 3.40 & 0.70 & 0.96 \\
\hline D (2011) & 87.50 & 5.75 & 3.90 & 1.63 & 1.22 \\
\hline E (2012) & 85.60 & 7.40 & 4.50 & 1.30 & 1.20 \\
\hline F (2013) & 83.00 & 7.9 & 5.00 & 2.20 & 1.90 \\
\hline G (2014) & 79.70 & 8.50 & 4.80 & 2.50 & 4.50 \\
\hline $\mathrm{H}(2015)$ & 78.73 & 11.19 & 4.25 & 2.85 & 2.13 \\
\hline I (2016) & 78.73 & 11.77 & 5.97 & 1.40 & 2.13 \\
\hline
\end{tabular}

Table 1. Variation of Percentage by volume of hydrocarbons (natural gas) flared in the oil field (Alpha-Field) under investigation.

Source: Alpha field data log sheet (2016). 
From the above, it is evident that the number of carbon atoms is the coefficient of $\mathrm{CO}_{2}$ at the product side of the combustion equation $=1.098$, while the number of hydrogen atoms is coefficient of $\mathrm{H}_{2} \mathrm{O} \times 2=2.089 \times 2=4.196$

Thus, the simple aggregated fuel for this gas composition is: $\mathrm{C}_{1.098} \mathrm{H}_{4.196}$

This will give rise to the following stoichiometric equation:

$$
\mathrm{C}_{1.098} \mathrm{H}_{4.196}+2.147\left(\mathrm{O}_{2}+3.7676 \mathrm{~N}_{2}\right) \rightarrow 1.098 \mathrm{CO}_{2}+2.098 \mathrm{H}_{2} \mathrm{O}+8.07272 \mathrm{~N}_{2}(18)
$$

A MATLAB program was developed to evaluate other gas samples as displayed on Table 2 .

Table 2 depicts the combustion characteristics of the natural gas. Column one is the natural gas sample for each year while column two is the aggregated fuel content. It is evident that as the year progresses, lighter components decreased while the heavier alkanes become predominant. Furthermore, the other columns show the number of moles of the stoichiometric air, $\mathrm{CO}_{2}, \mathrm{H}_{2} \mathrm{O}$, and nitrogen.

\subsection{Analysis of Amount of $\mathrm{CO}_{2}$ and Water Vapour $\left(\mathrm{H}_{2} \mathrm{O}\right)$ Produced for the First Year (2008)}

Analysis showed that for the fuel with composition, $\mathrm{C}_{1.098} \mathrm{H}_{4.196}$, for $1 \mathrm{~m}^{3}$ of the fuel that burns in air, $1.098 \mathrm{~m}^{3}$ of $\mathrm{CO}_{2}$ and $2.098 \mathrm{~m}^{3}$ of water vapour were respectively produced. Proportionately to get the quantities of flue gases, flare volume values are obtained from Table 3 as depicted below:

Flare volume for the year $(2008)=75,399,656.65 \mathrm{~m}^{3}$

Amount of $\mathrm{CO}_{2}$ produced per year $=1.098 \times 75,399,656.65=82,788,823.0017$ $\mathrm{m}^{3}$

Amount of $\mathrm{H}_{2} \mathrm{O}$ produced per year $=2.098 \times 75,399,656.65=158,188,479.6517$ $\mathrm{m}^{3}$

With the above analysis and with the help of MATLAB program codes, the following values are obtained in Table 3.

Table 2. Table of gas samples, fuel aggregates, amount of air and amount of flue gases after combustion.

\begin{tabular}{cccccc}
\hline Natural Gas sample & $\begin{array}{c}\text { Carbon-Hydrogen } \\
\text { fuel content }\end{array}$ & $\begin{array}{c}\text { Amount of } \\
\text { air per kmol of fuel }\end{array}$ & $\begin{array}{c}\text { Amount of } \mathrm{CO}_{2} \\
\text { produced per kmol }\end{array}$ & $\begin{array}{c}\text { Amount of } \mathrm{H}_{2} \mathrm{O} \text { per } \\
\text { kmol of fuel }\end{array}$ & $\begin{array}{c}\text { Amount of } \mathrm{N}_{2} \text { per } \\
\text { kmol of fuel }\end{array}$ \\
\hline A (2008) & $\mathrm{C}_{1.0980} \mathrm{H}_{4.1960}$ & 2.1470 & 1.098 & 2.0980 & 8.0727 \\
B (2009) & $\mathrm{C}_{1.1263} \mathrm{H}_{4.2400}$ & 2.1912 & 1.1263 & 2.1200 & 8.2254 \\
C (2010) & $\mathrm{C}_{1.1244} \mathrm{H}_{4.2296}$ & 2.1914 & 1.1244 & 2.1148 & 8.2132 \\
D (2011) & $\mathrm{C}_{1.1722} \mathrm{H}_{4.3200}$ & 2.2644 & 1.1722 & 2.1600 & 8.4805 \\
E (2012) & $\mathrm{C}_{1.1910} \mathrm{H}_{4.3580}$ & 2.2925 & 1.1910 & 2.1790 & 8.5867 \\
F (2013) & $\mathrm{C}_{1.2260} \mathrm{H}_{4.4140}$ & 2.3485 & 1.2260 & 2.2070 & 8.7779 \\
G (2014) & $\mathrm{C}_{1.1230} \mathrm{H}_{4.4400}$ & 2.3960 & 1.1230 & 2.2200 & 8.9179 \\
H (2015) & $\mathrm{C}_{1.2578} \mathrm{H}_{4.4730}$ & 2.3974 & 1.2578 & 2.2365 & 8.9552 \\
I (2016) & $\mathrm{C}_{1.1278} \mathrm{H}_{4.4730}$ & 2.3974 & 1.1278 & 2.2365 & 8.9552 \\
\hline
\end{tabular}


Table 3. Amount (volume) of Flue Gases for the period under investigation.

\begin{tabular}{cccccc}
\hline Year & $\begin{array}{c}\text { Production } \\
\text { volumes } \mathrm{m}^{3}\end{array}$ & $\begin{array}{c}\text { Flare volumes } \\
\mathrm{m}^{3}\end{array}$ & $\begin{array}{c}\text { Percentage } \\
\text { of gas } \\
\text { flared } \%\end{array}$ & $\begin{array}{c}\text { Quantity of } \\
\mathrm{CO}_{2}\left(\mathrm{~m}^{3}\right)\end{array}$ & $\begin{array}{c}\text { Quantity of } \\
\mathrm{H}_{2} \mathrm{O}\left(\mathrm{m}^{3}\right)\end{array}$ \\
\hline $\mathbf{2 0 0 8}$ & $169,668,539.73$ & $75,399,656.65$ & 44.44 & $82,788,823.0017$ & $158,188,479.6517$ \\
$\mathbf{2 0 0 9}$ & $414,918,078.66$ & $85,727,135.76$ & 20.66 & $96,554,469.6276$ & $181,741,527.8112$ \\
$\mathbf{2 0 1 0}$ & $355,971,341.25$ & $97,458,655.39$ & 27.38 & $109,582,512.1205$ & $206,105,564.4188$ \\
$\mathbf{2 0 1 1}$ & $313,273,834.34$ & $54,456,815.78$ & 17.37 & $63,834,279.4573$ & $117,626,722.0848$ \\
$\mathbf{2 0 1 2}$ & $128,155,262.21$ & $59,469,427.36$ & 46.40 & $70,828,087.9858$ & $129,583,882.2174$ \\
$\mathbf{2 0 1 3}$ & $229,335,870.54$ & $48,943,657.25$ & 21.34 & $60,004,923.7885$ & $108,018,651.5507$ \\
$\mathbf{2 0 1 4}$ & $\mathbf{6 6 , 6 5 6 , 4 0 1 . 9 1}$ & $31,132,508.91$ & 46.71 & $3,517,807.5059$ & $6,954,169.7802$ \\
$\mathbf{2 0 1 5}$ & $80,526,209.82$ & $37,847,318.61$ & 46.99 & $47,604,357.3476$ & $84,645,528.0713$ \\
$\mathbf{2 0 1 6}$ & $111,564,578.95$ & $50,588,818.23$ & 45.34 & $47,604,357.3476$ & $84,645,528.0713$ \\
\hline TOTAL & $1,870,070,117.41$ & $541,023,993.9$ & & $582,319,618.2$ & $1,077,510,054.31$ \\
\hline
\end{tabular}

\subsection{Estimation of Carbon (IV) Oxide for Comparison}

Using the relation $M A S S_{\mathrm{CO}_{2}}=\frac{M_{\text {flared gas }} \times M M_{\mathrm{CO}_{2}}}{M M_{\text {fuel }}}$, in the validation of the amount of $\mathrm{CO}_{2}$ as asserted by [20].

$$
M_{\text {flared gas }}=59791927.7266 \mathrm{~kg} / \text { year } ; M M_{\mathrm{CO}_{2}}=44 \mathrm{~g} / \mathrm{mol} ; \quad M M_{\text {fuel }}=17.372
$$

Substituting values, we have:

$$
\text { MASS }_{\mathrm{CO}_{2}}=\frac{59791927.7266 \mathrm{~kg} / \text { year } \times 44 \mathrm{~g} / \mathrm{kmol}}{17.372}=151441677.41 \mathrm{~kg}
$$

But density of $\mathrm{CO}_{2}=1.98 \mathrm{~kg} / \mathrm{m}^{3}$

Using the relation: Density $(\rho)=\frac{\text { mass }}{\text { volume }}=\frac{m}{V}$

$$
\text { Volume }=151441677.41 / 1.98=76485695.661 \mathrm{~m}^{3} / \text { year }
$$

The percentage correlation of this research work and that done by [20] is:

$$
\% \text { correlation }=76485695.661 / 82788823.0017=0.923864=92.28 \%
$$

Table 3 depicts the yearly natural gas production volumes, flared volumes, the percentage of gas flared for each year, the quantity of carbon (IV) oxide and water vapour produced. Analyses showed that total natural gas production over the nine-year period was estimated to be $1,870,070,117.41$ standard cubic meters from which 541,023,993.9 standard cubic meters was flared. This generated $582,319,618.2(\approx 1.046 \mathrm{MMt})$ cubic meter of $\mathrm{CO}_{2}$ and about 1,077,510,054.31 $(\approx 2.05 \mathrm{MMt})$ cubic meters of water vapour. Another analysis indicates that about $14,960,560.91$ standard cubic meters of methane was also discharged to the atmosphere through transient loses.

From Figure 1 and the results obtained showed that there is a linear variation (i.e. the quantity of $\mathrm{CO}_{2}$ increases with flared volumes.), same is applicable for 


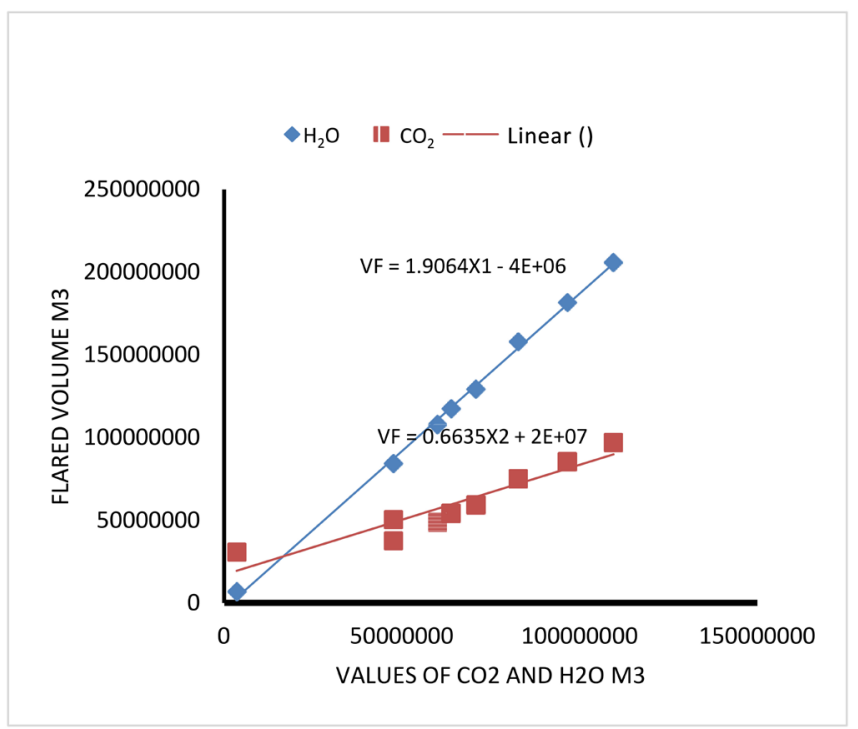

Figure 1. Plot of flared volume and variation in $\mathrm{CO}_{2}$ and $\mathrm{H}_{2} \mathrm{O}$.

water vapour. It is also evident that by the steepness of the lines, the amount of water vapour effluent is about twice that of carbon (IV) oxide. Also approximately $27 \%$ - $40 \%$ of gas produced in the field was flared.

\subsection{Analysis of Adiabatic Flame Temperature AFT for the First Year (2008)}

From Equation (2):

$$
\begin{aligned}
H_{R}= & \sum_{R} n_{i}\left(\bar{h}_{f}+\bar{\Delta}_{h}\right)_{i} \\
= & 0.939\left(\bar{h}_{o}+\bar{\Delta}_{h}\right)_{f}+0.036\left(\bar{h}_{o}+\bar{\Delta}_{h}\right)_{\mathrm{CH}_{4} \mathrm{H}_{6}}+0.013\left(\bar{h}_{o}+\bar{\Delta}_{h}\right)_{\mathrm{C}_{3} \mathrm{H}_{8}} \\
& +0.012\left(\begin{array}{c}
\bar{h}_{o}+\bar{\Delta}_{h} \\
f
\end{array}\right)_{\mathrm{C}_{4} \mathrm{H}_{10}}+2.147\left(\begin{array}{c}
\bar{h}_{o}+\bar{\Delta}_{h} \\
f
\end{array}\right)_{\mathrm{O}_{2}}+8.07272\left(\begin{array}{c}
\bar{h}_{o} \\
f
\end{array} \bar{\Delta}_{h}\right)_{\mathrm{N}_{2}}
\end{aligned}
$$

Since $\bar{h}_{o}$ for diatomic gases are zero, and $\bar{\Delta}_{h}$ for the fuel is also zero (reference temperature $25^{\circ} \mathrm{C}$ ) and also $\bar{\Delta}_{h}=300 \mathrm{~K}$

$$
\begin{aligned}
H_{R}= & 0.939\left(\begin{array}{c}
\bar{h}_{o} \\
f
\end{array}\right)_{\mathrm{CH}_{4}}+0.036\left(\bar{h}_{o}\right)_{f}+0.013\left(\bar{h}_{o}\right)_{f} \mathrm{C}_{6} \\
& +0.012\left(\overline{\mathrm{C}}_{\mathrm{C}_{3} \mathrm{H}_{8}}\right)_{f}+2.147\left(\bar{\Delta}_{h}\right)_{\mathrm{C}_{4} \mathrm{H}_{10}}+8.07272\left(\bar{\Delta}_{h}\right)_{\mathrm{N}_{2}}
\end{aligned}
$$

Substituting values from established standard thermodynamic tables from [21] we have:

$$
\begin{gathered}
H_{R}=0.939(-74873)+0.036(-84667)+0.013(-103874) \\
+0.012(-126148)+2.147(54)+8.07272(54) \\
H_{R}=-75666.03212 \mathrm{~kJ} / \mathrm{kmol}
\end{gathered}
$$

Similarly, for the products, we have: 


$$
\begin{aligned}
& H_{P}=\sum_{P} n_{e}\left(\begin{array}{c}
\bar{h}_{o} \\
f
\end{array} \bar{\Delta}_{h}\right)_{e} \\
& =1.098\left[\begin{array}{c}
\bar{h}_{o}+\bar{\Delta}_{h} \\
f
\end{array}\right]_{\mathrm{CO}_{2}}+2.098\left[\begin{array}{c}
\bar{h}_{o} \\
f
\end{array} \bar{\Delta}_{h}\right]_{\mathrm{H}_{2} \mathrm{O}}+8.07272\left[\begin{array}{c}
\bar{h}_{o}+\bar{\Delta}_{h} \\
f
\end{array}\right]_{\mathrm{N}_{2}} \\
& H_{P}=1.098(-393522)+1.098[\bar{\Delta} h]_{\mathrm{CO}_{2}}+2.098(-241827) \\
& +2.098(\bar{\Delta} h)_{\mathrm{H}_{2} \mathrm{O}}+8.07272[\bar{\Delta} h]_{\mathrm{N}_{2}} \\
& =-938440.202+1.098[\bar{\Delta} h]_{\mathrm{CO}_{2}}+2.098(\bar{\Delta} h)_{\mathrm{H}_{2} \mathrm{O}}+8.07272[\bar{\Delta} h]_{\mathrm{N}_{2}}
\end{aligned}
$$

Equating (19) \& (20), and solving the resulting equations, we have:

$$
\Rightarrow 1.098[\bar{\Delta} h]_{\mathrm{CO}_{2}}+2.098(\bar{\Delta} h)_{\mathrm{H}_{2} \mathrm{O}}+8.07272[\bar{\Delta} h]_{\mathrm{N}_{2}}=863774.16988
$$

By iterative thermodynamics and from standard tables of thermo-mechanical properties of selected substances [21], we have Table 4.

By linear interpolation

$$
\begin{gathered}
\frac{X-2300}{2400-2300}=\frac{863774.16988-846590.42}{893862.094-846590.42} \\
X=A F T=2336.351 \mathrm{~K}\left(2063.351^{\circ} \mathrm{C}\right)
\end{gathered}
$$

The value so calculated is the adiabatic flame temperature, and other values are calculated using MATLAB codes and are depicted in Figure 2.

The plot of Figure 2 indicates that from 2008 to 2016 the natural gas quality reduces, with a consequence of decrease of adiabatic flame temperature as shown by the profile of the graph. Apart from 2009 and 2010, the adiabatic flame temperatures decreased progressively.

\subsection{Estimation of Heat Flux (Thermal Pollution Rate)}

From the evaluated adiabatic flame temperature, the thermal pollution rate can be calculated as follows:

$$
\begin{aligned}
Q & =\sigma \epsilon T^{4} \\
& =5.67 \times 10^{-8} \mathrm{~W} / \mathrm{m}^{2} \cdot \mathrm{K}^{4} \times 1 \times\left(2336.351^{4}\right) \mathrm{K}^{4} \\
& =1.6380 \times 10^{6} \mathrm{~W} / \mathrm{m}^{2}
\end{aligned}
$$

Again MATLAB program was used to evaluate other values of the heat fluxes and values are depicted in Figure 3.

Table 4. Iterated values of the maximum temperature at the discharge of the flare stack, with given gas composition.

\begin{tabular}{cccc}
\hline \multirow{2}{*}{ Exhaust products } & \multicolumn{3}{c}{ Temperatures } \\
\hline $1.098(\bar{\Delta} h)_{\mathrm{CO}_{2}}$ & $120,418.76$ & - & $127,135.224$ \\
$2.098(\bar{\Delta} h)_{\mathrm{H}_{2} \mathrm{O}}$ & $185,242.91$ & - & $196,381.129$ \\
$8.07272(\bar{\Delta} h)_{\mathrm{N}_{2}}$ & $540,928.75$ & - & $570,345.741$ \\
$\Sigma$ & $846,590.42$ & $863,774.16988$ & $893,862.094$ \\
\hline
\end{tabular}




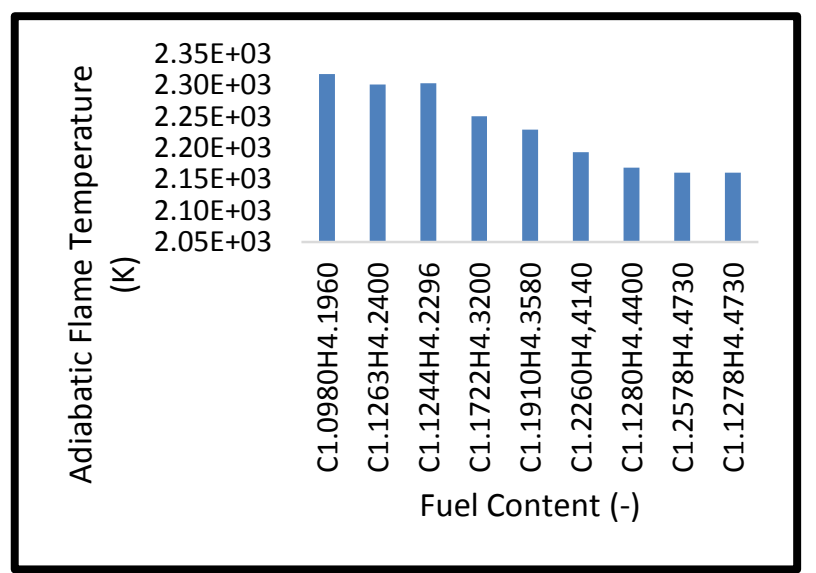

Figure 2. Plot of AFT and fuel content.

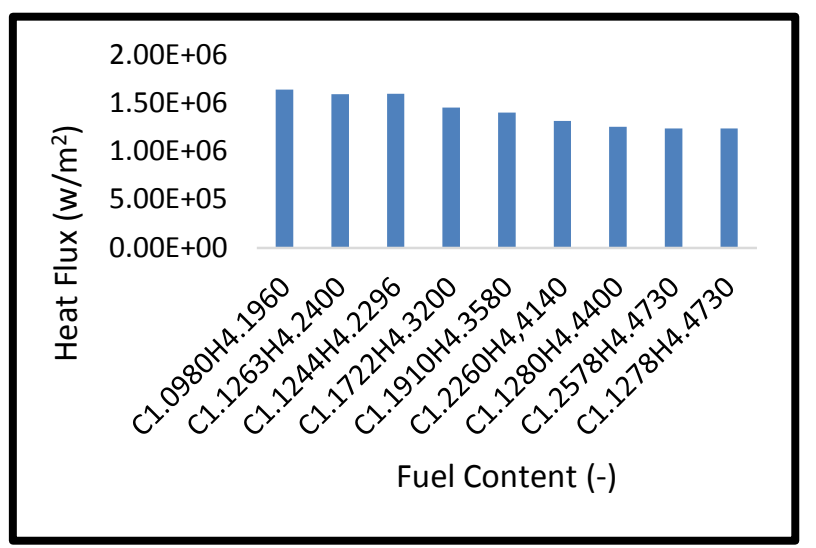

Figure 3. Plot of heat flux and fuel content.

From Figure 3, again there is a progressive decrease of heat flux density as the fuel constituent becomes heavier. Meaning that when the lighter components are predominant, the flame tends to be hotter, which is in tandem with the adiabatic flame temperatures. This enormous amount of heat is the reason why there is deficiency in crop yield production, decrease in microbes, and soil $\mathrm{PH}$, erosion of corrugated sheets in flare areas.

\subsection{Chemical Exergy Computation}

The molar analysis from the reference environmental model is:

$$
y_{\mathrm{N}_{2}}^{e}=0.7567 ; y_{\mathrm{O}_{2}}^{e}=0.2035 ; y_{\mathrm{H}_{2} \mathrm{O}}^{e}=0.0303 ; y_{\mathrm{CO}_{2}}^{e}=0.0003
$$

The balanced combustion equation is:

$$
\begin{gathered}
\mathrm{C}_{1.098} \mathrm{H}_{4.196}+2.147\left(\mathrm{O}_{2}+3.76 \mathrm{~N}_{2}\right) \rightarrow 1.098 \mathrm{CO}_{2}+2.098 \mathrm{H}_{2} \mathrm{O}+8.07272 \mathrm{~N}_{2} \\
e_{x, c h}=\left[\bar{g}_{F}+\left(a+\frac{b}{4}\right) \bar{g}_{\mathrm{O}_{2}}-a \bar{g}_{\mathrm{CO}_{2}}-\frac{b}{2} \bar{g}_{\mathrm{H}_{2} \mathrm{O}}\right]\left(T_{o}, P_{o}\right)+R T_{o} \ln \left[\frac{\left(y_{\mathrm{O}_{2}}^{e}\right)^{a+b / 4}}{\left(y_{\mathrm{CO}_{2}}^{e}\right)^{a}\left(y_{\mathrm{H}_{2} \mathrm{O}}^{e}\right)^{b / 2}}\right]
\end{gathered}
$$

Applying to the products of combustion and with the given composition of 
the environment and data from tables of thermochemical properties of selected substances at $298 \mathrm{~K}$ and $1 \mathrm{~atm}$ [21] the above equation yields:

$$
\begin{aligned}
e_{x, c h}=[-49026.89+(2.147)(0)-1.098(-394380)-2.098(-228590)]\left(T_{o}, P_{o}\right) \\
+(8.3144)(298) \ln \left[\frac{(0.2035)^{2.147}}{(0.0003)^{1.098}(0.0303)^{2.098}}\right] \\
e_{x, c h}=[-49026.89+433029.24+479581.82]+[31814.8984] \\
=863584.17+31814.8984 \\
=895399.1(\mathrm{~kJ} / \mathrm{kmol})
\end{aligned}
$$

Dividing through by the molecular weight of the fuel $(17.379 \mathrm{~kg} / \mathrm{kmol})$, we have $e_{x, c h}=\frac{895399.1}{17.379}=51521.8999(\mathrm{~kJ} / \mathrm{kg})$ Of the fuel

\subsection{Thermo-Mechanical Exergy Computation, $e_{x, T M}$}

Applying ideal gas models, the thermo-mechanical contribution of the flue gases per kmol of fuel with, $T=A F T=2336.351 \mathrm{~K}\left(2063.351^{\circ} \mathrm{C}\right)$. We have:

$$
\begin{aligned}
\bar{h} & -\overline{h_{o}}-T_{O}\left(\bar{s}-\overline{s_{o}}\right) \\
= & 1.098\left[\bar{h}(T)-\bar{h}\left(T_{O}\right)-T_{O}\left(\bar{s}^{O}(T)-\bar{s}_{o}^{O}\left(T_{O}\right)\right)-R \ln \left(\frac{y_{\mathrm{CO}_{2}, P}}{y_{\mathrm{CO}_{2}, P_{O}}^{e}}\right)\right] \mathrm{CO}_{2} \\
& +2.098\left[\bar{h}(T)-\bar{h}\left(T_{O}\right)-T_{O}\left(\bar{s}^{O}(T)-\bar{s}_{o}^{O}\left(T_{O}\right)\right)-R_{O} \ln \left(\frac{y_{\mathrm{H}_{2} \mathrm{O}, P}}{y_{\mathrm{H}_{2} \mathrm{O}, P_{O}}^{e}}\right)\right] \mathrm{H}_{2} \mathrm{O} \\
& +8.07272\left[\bar{h}(T)-\bar{h}\left(T_{O}\right)-T_{O}\left(\bar{s}^{O}(T)-\bar{s}_{o}^{O}\left(T_{O}\right)\right)-R_{O} \ln \left(\frac{y_{\mathrm{N}_{2}, P}}{y_{\mathrm{N}_{2}, P_{O}}^{e}}\right)\right] \mathrm{N}_{2}
\end{aligned}
$$

Since $P=P_{O}$, each of the logarithmic terms drop out, also $T$ is the adiabatic flame temperature, and $\overline{h_{o}}$ and ${\overline{s_{o}}}^{O}$ are data at $T_{O}$ from standard tables for ideal gas properties of selected gases [21], the thermo-mechanical contribution is:

$$
\begin{aligned}
& \bar{h}-\overline{h_{o}}-T_{O}\left(\bar{s}-\overline{s_{o}}\right) \\
&= 1.098\left[\bar{h}(T)-\bar{h}\left(T_{O}\right)-T_{O}\left(\bar{s}^{O}(T)-{\overline{s_{o}}}^{O}\left(T_{O}\right)\right)\right] \mathrm{CO}_{2} \\
&+2.098\left[\bar{h}(T)-\bar{h}\left(T_{O}\right)-T_{O}\left(\bar{s}^{O}(T)-{\overline{s_{o}}}^{O}\left(T_{O}\right)\right)\right] \mathrm{H}_{2} \mathrm{O} \\
&+8.07272\left[\bar{h}(T)-\bar{h}\left(T_{O}\right)-T_{O}\left(\bar{s}^{O}(T)-{\overline{s_{o}}}^{O}\left(T_{O}\right)\right)\right] \mathrm{N}_{2} \\
& \bar{h}- \overline{h_{o}}-T_{O}\left(\bar{s}-\overline{s_{o}}\right) \\
&= 1.098[121235.32-9364-298(318.642-213.685)] \mathrm{CO}_{2} \\
&+ 2.098[(100104.84-9904)-298(272.659-188.720)] \mathrm{H}_{2} \mathrm{O} \\
&+ 8.07272[(76986.4-8669)-298(257.59-191.502)] \mathrm{N}_{2} \\
& \bar{h}-\overline{h_{o}}-T_{O}\left(\bar{s}-\overline{s_{o}}\right)=87889.4391+136762.364+392521.2854=617183.1(\mathrm{~kJ} / \mathrm{kmol})
\end{aligned}
$$


of the fuel.

Dividing through by the molecular weight of the fuel, we have the value in $\mathrm{kJ} / \mathrm{kg}$ as:

$$
\bar{h}-\overline{h_{o}}-T_{O}\left(\bar{s}-\overline{s_{o}}\right)=\frac{617183.1(\mathrm{~kJ} / \mathrm{kmol})}{17.379(\mathrm{~kg} / \mathrm{kmol})}=35513.153(\mathrm{~kJ} / \mathrm{kg}) \text { of the fuel. }
$$

\subsection{Total Specific Exergy Computation}

The total exergy from Equation (13) is:

$$
\begin{aligned}
e_{x, T} & =e_{x, T M}+e_{x, c h} \\
& =35513.153(\mathrm{~kJ} / \mathrm{kg})+51521.8999(\mathrm{~kJ} / \mathrm{kg}) \\
& =87035.0529(\mathrm{~kJ} / \mathrm{kg})
\end{aligned}
$$

which is the exergy per unit mass.

\subsection{Total Exergy Computation for the Period under Review}

From Table 3 the total flare volume for the first year 2008 is:

$$
\begin{gathered}
V_{f}=75399656.65 \mathrm{~m}^{3} / \text { year } \\
\rho_{g a}=0.713 \mathrm{~kg} / \mathrm{m}^{3}
\end{gathered}
$$

$\therefore$ The mass of flared gas $=$ density $\times$ flared volume $\left(V_{f}\right)$

$$
\begin{aligned}
& =0.713 \mathrm{~kg} / \mathrm{m}^{3} \times 75399656.65 \mathrm{~m}^{3} / \text { year } \\
& =53759955.19 \mathrm{~kg} / \text { year }
\end{aligned}
$$

Hence, total exergy, $E_{X, T}$ :

$$
\begin{aligned}
E_{X, T_{1}} & =e_{x, T} \times 59791927.7266 \mathrm{~kg} / \text { year } \\
& =87035.0529(\mathrm{~kJ} / \mathrm{kg}) \times 59791927.7266 \mathrm{~kg} / \text { year } \\
& =4.6789 \times 10^{12} \mathrm{~kJ} / \text { per year }
\end{aligned}
$$

\subsection{The Electrical Equivalent of the Total Exergy}

The electrical equivalent of the total exergy so calculated is $=5.204 \times 10^{12} \times 0.0002778 \mathrm{kWh}=1300761.361 \mathrm{kWh}$ of electricity for that year.

Thus, with the different density values of the gas compositions and with the help of MATLAB program, results are shown in Table 5.

From Table 5 flared volume and total exergy showed that the more gas flared in the field the more the exergy (work potential). Correspondently, the exergy is dependent on the amount of gas flared, with the highest exergy corresponding to 2010 and the least exergy to 2016. The total exergy over the period from Table 5 is estimated to be $3.6099 \times 10^{13} \mathrm{~kJ}(36.099 \mathrm{TJ})$ this exergy value would have translated to $1.0189 \times 10^{10} \mathrm{kWh}$ of electrical energy.

\section{Conclusions}

This research discussed the thermo-mechanical and environmental assessment 
Table 5. Specific, total and electric energy values.

\begin{tabular}{cccc}
\hline Natural Gas sample & $\begin{array}{c}\text { Specific exergy } \\
(\mathrm{kJ} / \mathrm{Kg})\end{array}$ & $\begin{array}{c}\text { Total exergy } \\
(\mathrm{kJ}) \times 10^{12}\end{array}$ & $\begin{array}{c}\text { Electrical energy } \\
(\mathrm{kWh}) \times 10^{9}\end{array}$ \\
\hline A (2008) & 85,561 & 4.6789 & 1.3007 \\
B (2009) & 87,141 & 5.5056 & 1.5295 \\
C (2010) & 86,966 & 6.2635 & 1.7399 \\
D (2011) & 88,561 & 3.7087 & 1.0303 \\
E (2012) & 88,974 & 4.1272 & 1.1465 \\
F (2013) & 90,908 & 3.5951 & 0.9987 \\
G (2014) & 91,892 & 2.3659 & 0.6572 \\
H (2015) & 90,974 & 2.9266 & 0.8930 \\
I (2016) & 90,974 & 2.9266 & 0.8930 \\
Total & 801,951 & 36.099 & 10.1888 \\
\hline
\end{tabular}

of flared gases in an oil field. The study proffered solution to the objectives of this research work, which are:

1) Combustion analysis carried out with the aid of fundamental thermodynamic combustion equations and with the help of the equation by [19] and the flared volumes, densities, molar masses, the amounts of carbon (IV) oxide, water vapour, and methane are estimated at $582,319,618.1825 \mathrm{~m}^{3}$ ( $\approx 1.046$ million tons), $1,077,510,054.31 \mathrm{~m}^{3}$ ( $\approx 2.0$ million tons) and $14,960,560.91 \mathrm{~m}^{3}$ respectively, which are all greenhouse gases and therefore very pernicious to the natural environment. The research also showed that the equation by [20] for quantifying the amount of carbon (IV) oxide has a $92.3 \%$ correlation with this research.

2) In fulfilling further objectives, the adiabatic flame temperatures were precisely evaluated using thermodynamic equations, correctly written combustion equations, different gas compositions, iterative thermodynamics, interpolations and with the help of MATLAB program. The adiabatic flame temperatures as evaluated in this work for natural gas also averagely correlated with those quoted in other literatures and are approximately $1965^{\circ} \mathrm{C}$, this is also in line with the inlet temperatures of gas turbines. The concept of exergy and related equations were also applied, this encompassed thermo-mechanical and chemical exergies to evaluate the total exergy which was found to be $3.6099 \times 10^{13} \mathrm{~kJ}$ (36.099 TJ) translating to $1.0189 \times 10^{10} \mathrm{kWh}$ amount of electrical energy. The report also reveals that about $27 \%$ - $40 \%$ of gas produced in the field for the period under investigation was flared.

In conclusion therefore, if only one oil Field gave such astronomical amount of exergy, it then means that enormous amount of energy loss have been incurred in flaring gas from all the oil fields in the Niger Delta region of Nigeria which otherwise would have been utilized to generate electricity or for other useful purposes. 


\section{Acknowledgements}

The researchers sincerely thank the Operator of the Alpha-Field for the opportunity to use their company as a case study. Data retrieved, interview with relevant personnel, Field visitations were very instrumental to the success of this research work.

\section{Conflicts of Interest}

The authors declare no conflicts of interest regarding the publication of this paper.

\section{References}

[1] Hart, H.I. (2018) Sustainable Electricity Generation in Nigeria: of Enthalpy, Entropy, Exergy and All That, Not Politics. An Inaugural Lecture at the Rivers State University. Series No. 53.

[2] Nii, N. (2005) National Energy Policy and gas flaring in Nigeria. Journal of Environmental and Earth Science, 5, 58-62.

[3] Chineme, O. (2017) NNPC: Nigeria Drops to Seventh Highest Gas Flaring Country. This Day News (03/04/2017).

[4] Oyedepo, S.O., Fagbenle, R.O., Adefila, S.S. and Adavbiele, S.A. (2013) Performance Evaluation and Economic Analysis of Gas Turbine Power Plants in Nigeria. Elsevier Journal of Energy Conversion Management, 79, 431-440. https://doi.org/10.1016/j.enconman.2013.12.034

[5] Ismial, O.S. and Fagbenle, R.O. (2009) Accurate Safety Zone Determination during Gas Flaring. Journal of Engineering and Applied Sciences, 4, 295-302.

[6] Abdulkadir, M., Isah, A.G. and Sani, Y. (2013) The Effects of Gas Faring on the Environment and Its Utilization (Case Study of Selected Villages in the Niger Delta Area Nigeria). Journal of Basic and Applied Scientific Research, 3, 238-291.

[7] Tsokos, C.P. and Xu, Y. (2009) Modelling Carbon Dioxide Emission with a System of Differential Equation: Nonlinear Analysis. International Journal of Exergy, 10, 422-453.

[8] Ubani, E.C. and Onyejekwe, I.M. (2013) Environmental Impact Analysis of Gas Flaring in the Niger Delta region of Nigeria. American Journal of Scientific and Industrial Research, 4, 246-252. https://doi.org/10.5251/ajsir.2013.4.2.246.252

[9] Aniefiok, E.I. and Udo, J.I. (2013) Gas Flaring and Venting Associated with Petroleum Exploration and Production in the Nigeria's Niger Delta. American Journal of Environmental Protection, 1, 70-77. https://doi.org/10.12691/env-1-4-1

[10] Ismail, S.O. and Umukoro, G.Z. (2012) Global Impact of Gas Flaring. Journal of energy and power Engineering, 4, 290-320. https://doi.org/10.4236/epe.2012.44039

[11] Dung, E.J., Bombom, L.S. and Agusumo, T.D. (2008) Effects of Gas Flaring on Crops in the Niger Delta, Nigeria. GeoJournal, 73, 297-305. https://doi.org/10.1007/s10708-008-9207-z

[12] Sosimo, E.D., Abel, H., Enric, S. and Chavez, R.H. (2012) Extended Exergy Accounting Applied to the Flaring Practices in Oil Fields. Theory, Methods and Applications, 71, 1182-1197.

[13] Ismail, O. and Adewale, O.S. (2012) Performance Evaluation and Environmental Impact Assessment of Systems with Waste Exergy Emissions. Intentional Journal of Scientific \& Engineering Research, 3, No. 7. 
[14] Olawale, S.I. and Kazeem, T. (2016) Exergy Analysis of Waste Emissions from Gas Flaring. Leonardo Electronic Journal of Practices and Technology, 28, 169-178.

[15] Nguyen, T.V., Leonardo, P., Brian, E., Fredrick, H., Peter, B. and Mari, V. (2013) Exergy Assessment of Energy Systems in North Sea Oil Platforms. Journal of Engineering Science and Technology, 62, 23-36.

[16] Emam, E.A. (2015) Gas Flaring in Industry: An Overview. Department of Chemical Eng. and pet. Refinery, Suez University. Egypt. Petroleum \& coal 57(5), 532-555.

[17] Ojijiagwo, E., Chike, F. and Nwabueze, E. (2016) Economics of Gas to Wire Technology Applied in Gas Flare Management. Engineering Science and Technology, 19, 2109-2118. https://doi.org/10.1016/j.jestch.2016.09.012

[18] Ochuko, A. (2015) Evaluating the Thermal Impact of Gas Flaring in Kokori, Southern Nigeria. Journal of Applied Physics Research, 7, 78-83. https://doi.org/10.5539/apr.v7n1p78

[19] Kaushik, S.C. and Singh, O.K. (2013) Estimation of Chemical Exergy of Solid, Liquids and Gaseous Fuels used in Thermal Power Plants. Journal of Thermal and Analytical Calorimetry, 115, 903-908.

[20] Nwanya, S.C. (2011). Climate Change and Energy Implications of Gas Flaring for Nigeria. International Journal of Low-Carbon Technologies, 3, 193-199. https://doi.org/10.1093/ijlct/ctr007

[21] Moran, J.M., Howard, N.S., Daisic, D.B. and Margaret, B.B. (2011) Fundamentals of Engineering Thermodynamics. 7th Edition, John Wiley and Sons, Inc., Hoboken.

\section{Nomenclature}

$P_{o}=$ Ambient pressure $[\mathrm{kpa}]$

$T_{o}=$ Ambient temperature $[\mathrm{K}]$

$a=$ No of moles of carbon [kmol]

$b=$ No of moles of hydrogen [kmol]

$A F T=$ Adiabatic flame temperature $[\mathrm{K}]$

$\Delta H^{C}=$ Enthalpy of combustion $[\mathrm{kJ} / \mathrm{kg}]$

$I T=$ Iterative thermodynamic

$e_{x}=$ Specific Exergy $[\mathrm{kJ} / \mathrm{kg}]$

$E_{x}=$ Total Exergy $[\mathrm{kJ}]$

$R=$ Universal gas constant $[\mathrm{kJ} / \mathrm{kmolk}]$

IOCs = International Oil Companies

$\bar{g}_{F}=$ Gibb's function of formation $[\mathrm{kJ} / \mathrm{kmol}]$

$E_{p}=$ Electrical Power generated $[\mathrm{kWh}]$

$\bar{h}_{f}^{\mathrm{o}}=$ Molar enthalpy of formation $[\mathrm{kJ} / \mathrm{kmol}]$

$y=$ Mole fraction

$V_{f}=$ flared volume $\left[\mathrm{m}^{3}\right]$

$\mathrm{T} \mathrm{J}=$ Terajoules 